\title{
Mineralogical, Geochemical, and Mechanical Characteristics of Intrusive Andesite Rock Slope in Sangon 2 Area, Kulon Progo Regency, Indonesia
}

\author{
Hnin Thandar Phyu ${ }^{1}$, Heru Hendrayana ${ }^{* 2}$, I Gde Budi Indrawan² ${ }^{2}$ and Toshitaka Kamai ${ }^{3}$ \\ ${ }^{1}$ Geology Department, University of Yangon and Taungoo University, Myanmar \\ ${ }^{2}$ Department of Geological Engineering, Faculty of Engineering, Universitas Gadjah Mada, Yogyakarta, Indonesia \\ ${ }^{3}$ Geohazards Research Center on Landslides, DPRI, Uji Campus, Kyoto University, Kyoto, Japan
}

\begin{abstract}
This study was carried out to investigate mineralogical, geochemical, and mechanical characteristics of intrusive andesite rock consisting of Sangon 2 Slope located in Kulon Progo Mountains. Mineralogical characteristics of the rock samples were identified by visual observation of hand specimens in the field, petrographic, X-ray Diffraction (XRD), and X-ray Fluorescence (XRF) analyses in the laboratory. The classification of the rocks was determined from these analyses. The presence of key minerals determined types of rock hydrothermal alterations identified in the petrographic and XRD analyses. The percentage of primary minerals (91.90 to $21.40 \%)$ to secondary minerals $(8.10$ to $78.60 \%)$ determined hydrothermal alteration intensities based on the petrographic analyses of thin sections by point counting method. Chemical Index of Alteration (CIA) of the rock samples was determined based on the laboratory results of XRF analysis. The classification of visual observations in the field and the rock uniaxial compressive strength (UCS) using point load and compression tests conducted in the laboratory to know the rock weathering degrees. The results showed that the rock typically consisted of $65.83 \%$ plagioclase, $3.70 \%$ quartz, and $7.50 \%$ hornblende, therefore, classified as andesite. The presence of chlorite and calcite as secondary minerals in the andesite rock samples indicated that the parent andesite rock had undergone propylitic alteration. Meanwhile, the percentages of primary minerals 91.90 to $21.40 \%$ indicated that the andesite rock had undergone weak to high alteration intensities. The CIA values of the rock samples increased 56.40 to $83.29 \%$ with the increase of rock weathering degrees. Based on the visual characteristics, the research area consists of fresh, slight, moderate, high, and complete weathered andesite rock, and residual soil. Rock weathering degrees identified by the visual characteristics appeared to be in good agreement with those classified based on the results of mineralogical, geochemical, and engineering characteristics. The strong andesite rock zone consists of rarely fresh andesite, slight, and moderate weathered andesite rocks. Very strong rocks at depth $(\sim 17 \mathrm{~m})$ had relatively 145.09 to $222.02 \mathrm{MPa}$ (high strength). Meanwhile, high and complete weathered andesite rock and residual soil dominantly occurred in the weak zone where is at the upper part of the slope profiles. High and complete weathered andesite rock had 4.78 to $0.41 \mathrm{MPa}$ (very weak compressive strength).
\end{abstract}

Keywords: Andesite · Hydrothermal alteration · Propylitic alteration · Weathering $\cdot$ Kulon Progo.

\footnotetext{
${ }^{*}$ Corresponding author: H. HendRayanA, Department of Geological Engineering, Universitas Gadjah Mada. Jl. Grafika 2 Yogyakarta, Indonesia. E-mail: heruha@ugm.ac.id
}

\section{INTRODUCTION}

The research investigated at the Sangon 2 Slope. The $27.1 \mathrm{~m}$ high, $90 \mathrm{~m}$ long slope had approximately $47^{\circ}$ inclination. The location of the slope 
is in the south part of Mt. Ijo, Kulon Progo Mountains, Yogyakarta, Indonesia (Figure 1). Referring to Regional Geological Map of Yogyakarta produced by Rahardjo et al. (1995), the area consists mainly of intrusive igneous rock andesite, which was formed by the activity of Tertiary magmatism (Figure 2).

In the past, Sangon 2 was a forested natural slope. However, the excavation of the slope made for the fulfillment of construction materials of the New Yogyakarta International Airport. Andesite has commonly very high compressive strength and consists of steep slopes. However, numerous studies, such as Lenggono et al. (2018), Pratama et al. (2018), showed that the intrusive rocks exposed at several locations in Mt. Ijo, one of Kulon Progo Mountains had undergone hydrothermal alterations, particularly propylitic and argillic alteration types. The altered rocks in the tropical humid climate had caused also rock weathering. Hydrothermal alteration and rock weathering processes caused several slope failures in Indonesia described statistically by Makealoun et al. (2014). These two processes were likely to have changed mineralogical, geochemical, and mechanical properties of the parent igneous rock. Determination of the mineralogical and geochemical characteristics of the andesite is, therefore, essential for understanding the rock engineering properties and behaviors as construction and slopeforming materials.

This paper presents preliminary results of a study carried out to investigate mineralogical, geochemical, and mechanical characteristics of intrusive igneous rock andesite in Sangon 2 slope. This study expected to provide information for andesite rock mines, particularly to explore safety mine slope design and materials selection.

\section{Research Method}

The location of the Sangon 2 mine slope is at coordinate $396765.99 \mathrm{E}, 9133582 \mathrm{~N}$ UTM map 49S. The research conducted field characteristics and laboratory works in Sangon 2 mine slope. During the field observation, eighteen profiles divided in the slope for observation of detailed rock mass structures and the condition of weak zone consists of high, complete weathered andesite and residual soil (Figure 4),
TABLE 1. Classification of rock hydrothermal alteration intensity (Gillis et al., 2014).

\begin{tabular}{lc}
\hline Alteration intensity & $\begin{array}{c}\text { Secondary minerals to } \\
\text { primary minerals }(\%)\end{array}$ \\
\hline Fresh rock & $<2$ \\
Weak & $02-9$ \\
Moderate & $10-49$ \\
High & $50-95$ \\
Intensive & $>90$ \\
\hline
\end{tabular}

at which characterization of rock masses was carried out by window mapping (Figure 3a). Mineralogical characteristics of the rocks consisting the slope were identified by visual observation of hand specimens in the field, petrographic and X-Ray Diffraction (XRD) analyses of the rock samples in the laboratory of Geohazards Research Center on Landslides, DPRI, Uji Campus, Kyoto University, Kyoto, Japan, upon which rock genetic classification was determined based on the igneous rock classification proposed by Streckeisen (1980). The presence of key minerals determined the types of rock hydrothermal alteration identified in the XRD analyses. The percentages of primary minerals of the rock samples observed in the petrographic analysis of thin sections by point counting method following the procedure described in Byers (1990). The percentages of secondary minerals of the rock samples were then subtracted percentages of total minerals and primary minerals. The percentages of secondary minerals could determine the hydrothermal alteration intensities by comparing the results. The classification of hydrothermal alteration intensities following proposed by Gillis et al. (2014), as shown in Table 1.

Rock weathering degrees determined in the field and X-Ray Fluorescence (XRF) analyses. Rock samples for XRD and XRF analyses conducted in the laboratory of Geohazards Research Center on Landslides, DPRI, Uji Campus, Kyoto University, Kyoto, Japan. In the field, rock weathering degrees determined based on the visual characteristics, following classification proposed by ISRM (2007, in Martin and Stacey, 2018), as shown in Table 2. In the laboratory, the rock weathering degree was determined based on the Chemical Index of Alteration (CIA) of the rock samples, following 


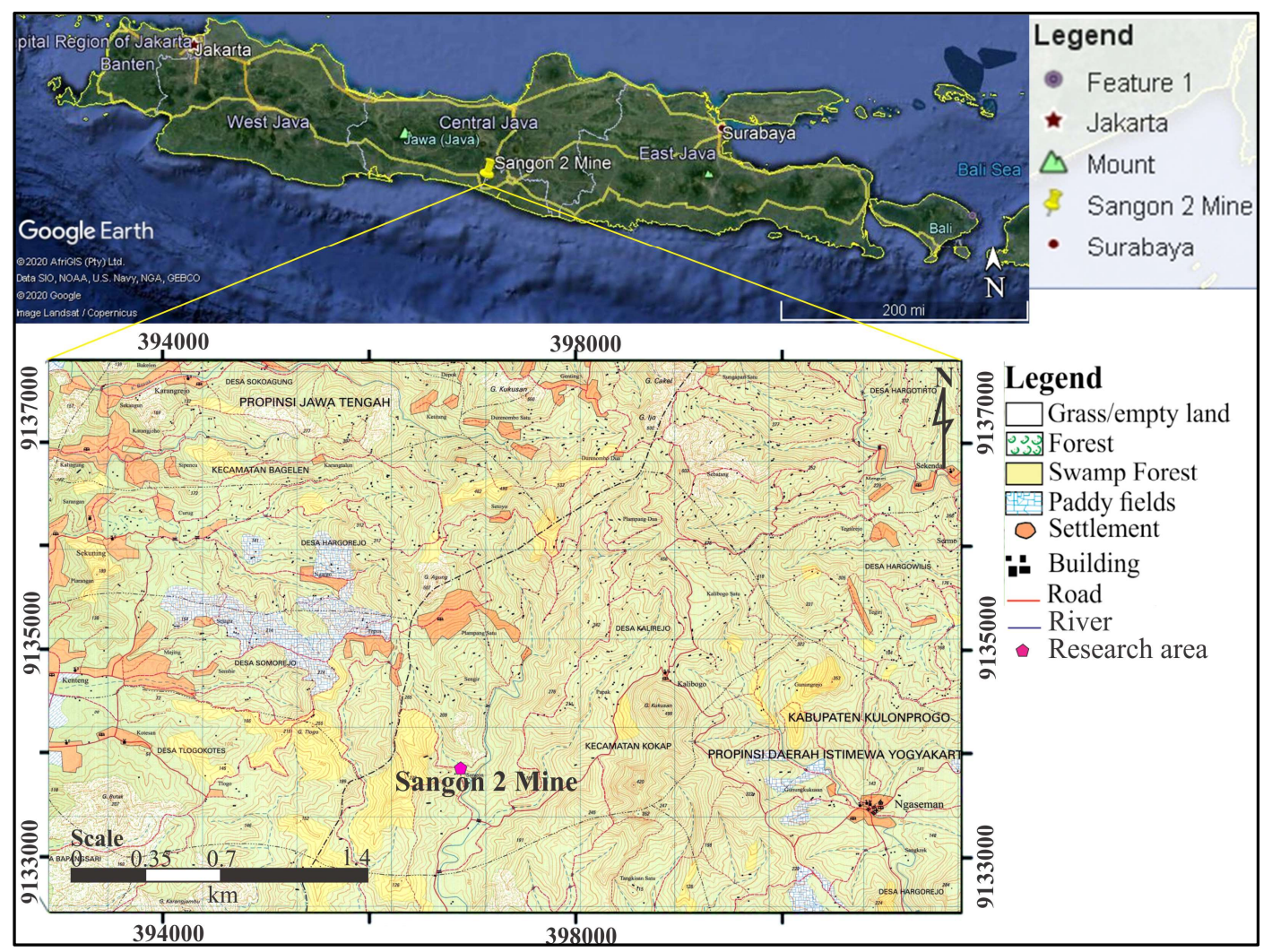

FIGURE 1. Research location.

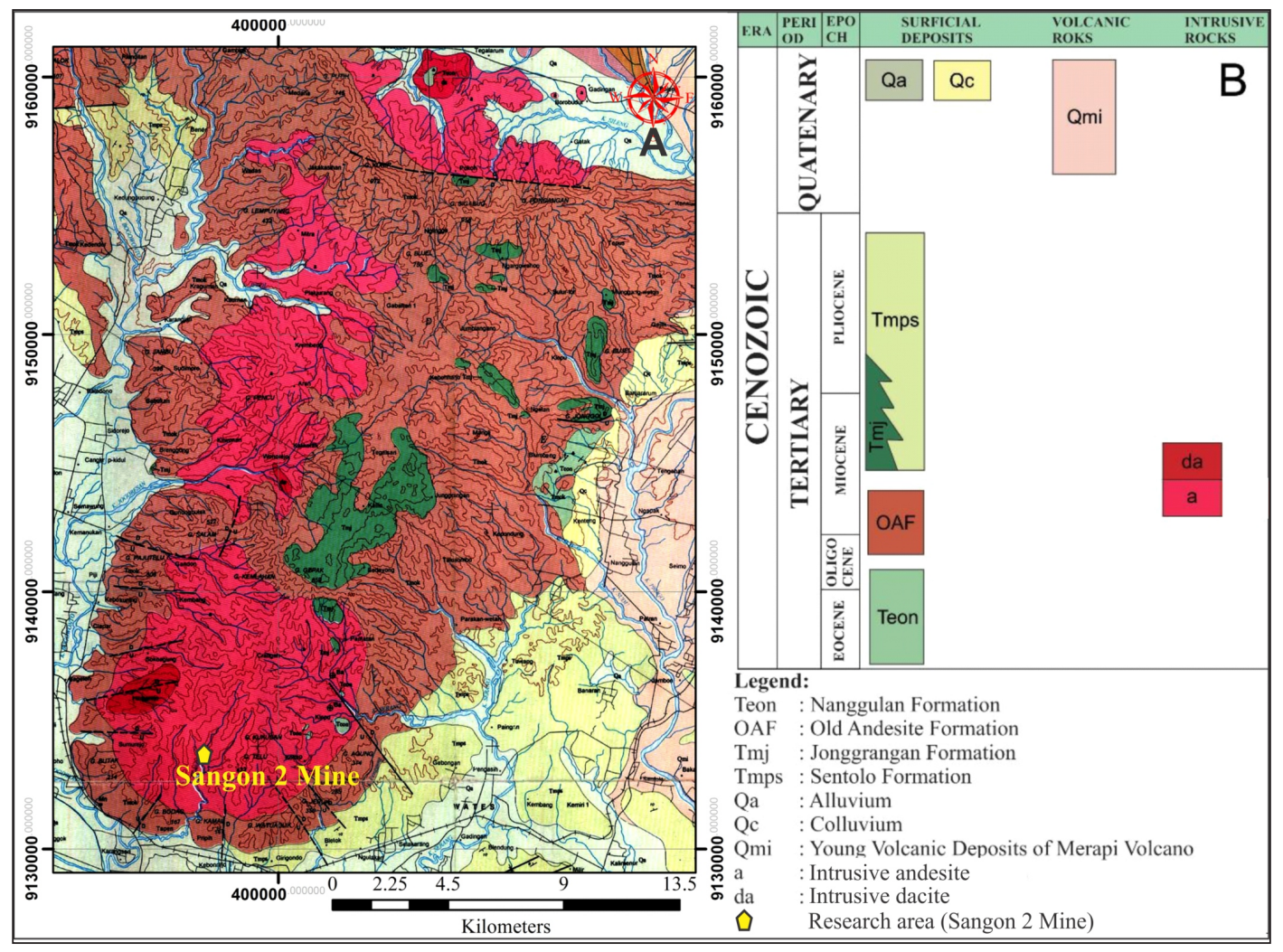

FIGURE 2. Part of the regional geological map of Yogyakarta and the stratigraphic sequence, according to Rahardjo et al. (1995). 


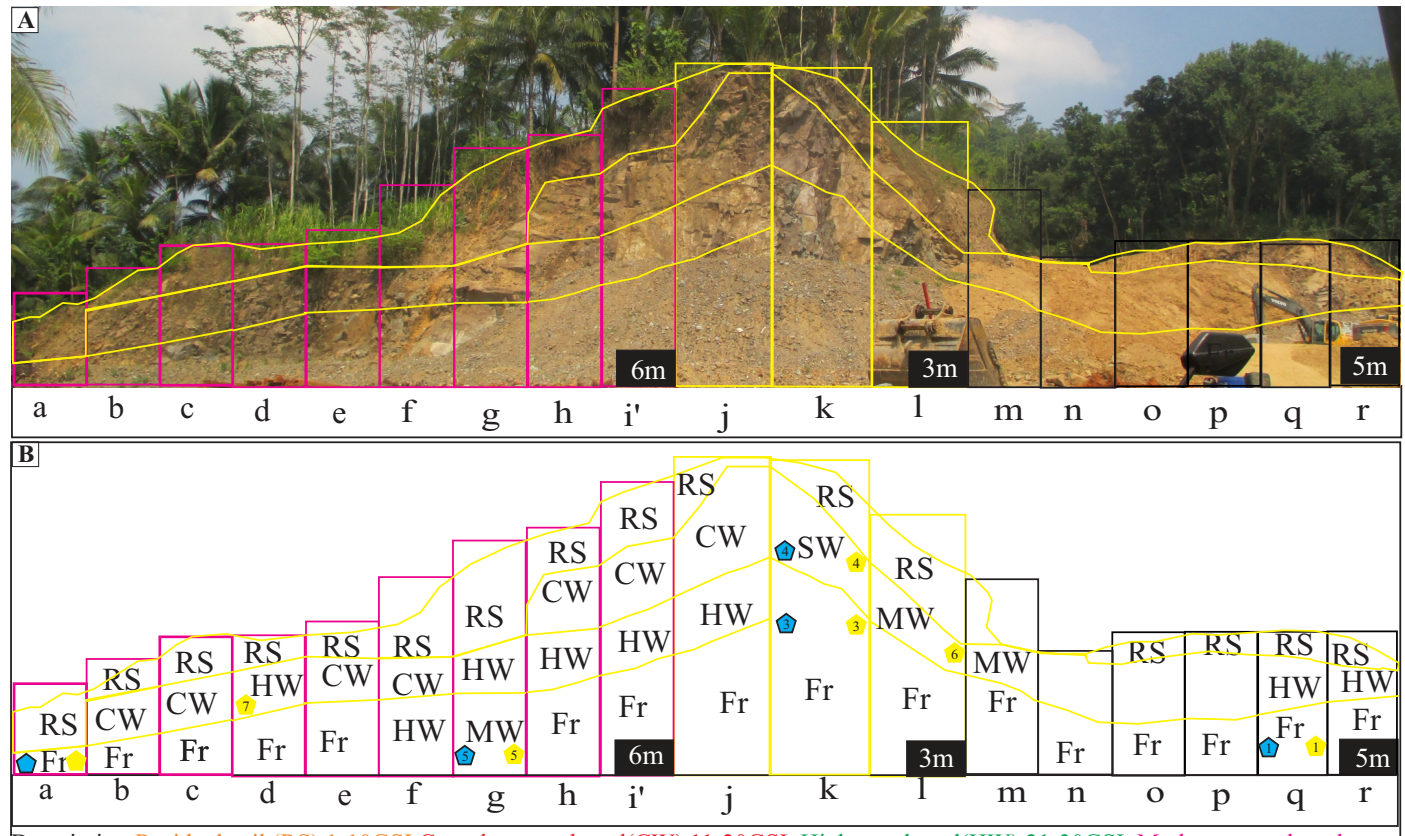

Description:Residual soil (RS) 1-10GSI,Complete weathered(CW) 11-20GSI, High weathered(HW) 21-30GSI, Moderate weathered (MW) 31-40GSI,Slightly weathered (SW)41-55GSI,Fresh rock andesite (FR) 56-70GSI, = =petrographic samples, $\square=$ XRD \& XRF sample

FIGURE 3. Overall view of the Sangon 2 mine: (a) Photograph of the slope; (b) Weathering profiles.

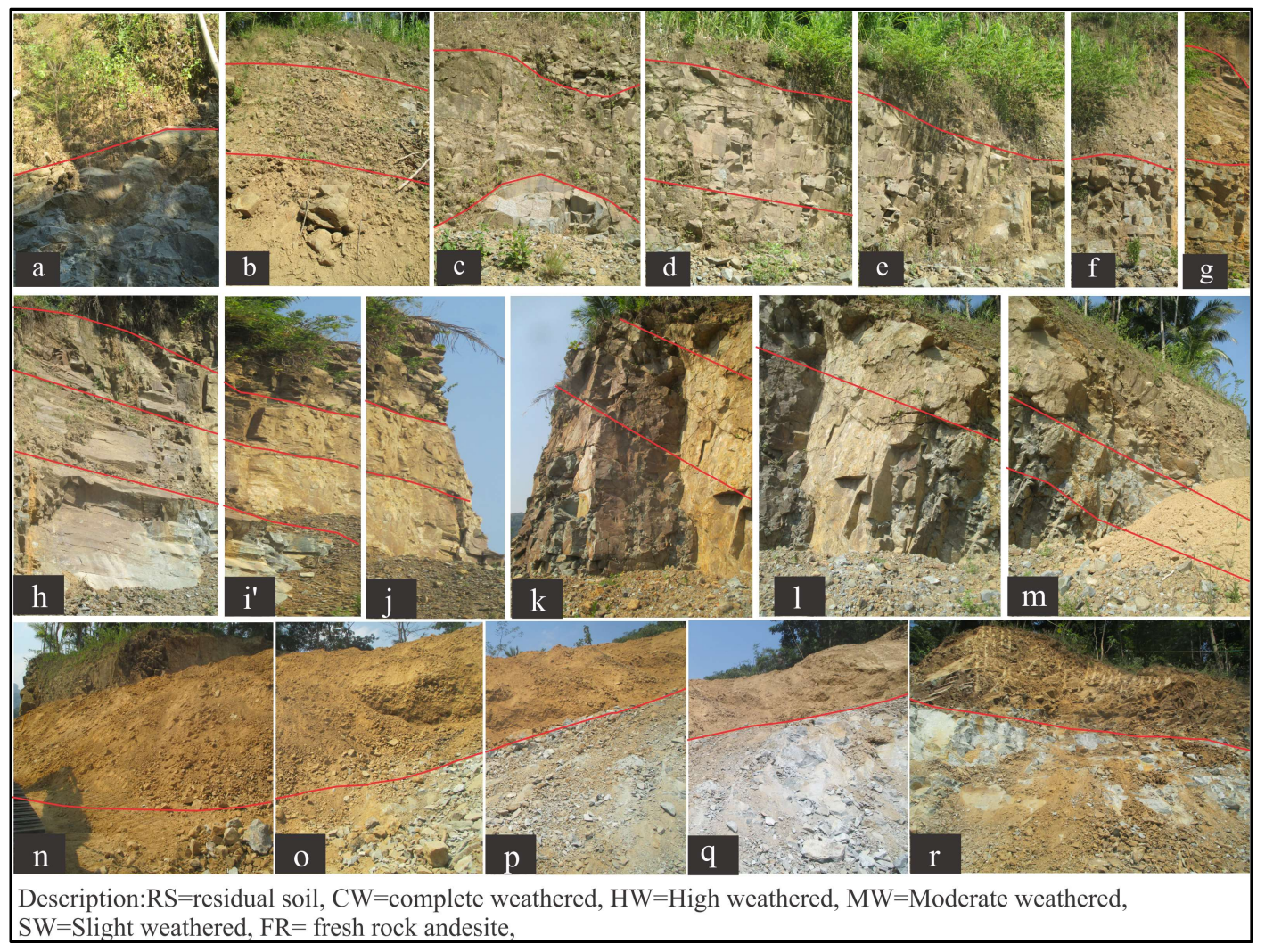

FIGURE 4. Photographs of the Sangon 2 slope profiles. 
classification proposed by Nesbitt and Young (1982), as shown in Table 3. The CIA values of the rock samples were calculated based on geochemical data of four major oxides obtained from XRF analyses using the following equation originally proposed by Nesbitt and Young (1982).

$$
\mathrm{CIA}(\%)=\frac{\mathrm{Al}_{2} \mathrm{O}_{3}}{\mathrm{Al}_{2} \mathrm{O}_{3}+\mathrm{CaO}+\mathrm{Na}_{2} \mathrm{O}+\mathrm{K}_{2} \mathrm{O}} \times 100
$$

where $\mathrm{Al}_{2} \mathrm{O}_{3}=$ aluminum oxide; $\mathrm{CaO}=$ calcium oxide; $\mathrm{Na}_{2} \mathrm{O}=$ sodium oxide; and $\mathrm{K}_{2} \mathrm{O}$ $=$ potassium oxide. As plagioclase is the most abundant mineral in the andesite rocks, high CIA values indicate the removal of $\mathrm{Ca}^{2+}, \mathrm{Na}^{+}$, and $\mathrm{K}^{+}$relative to static residual constituents $\left(\mathrm{Al}^{3+}\right)$ during weathering.

Point load tests following procedures described in Franklin (1985) that can determine the rock uniaxial compressive strength (UCS). The collection of five rock samples to know UCS values, seven rock samples to analyze point counting, eight rock samples, and two residual soil samples to analyze XRD and XRF made during field investigation.

The detailed descriptions of eighteen slope profiles in Figure 4 were as follow:

a. The slope profile (a) is a $6 \mathrm{~m}$ wide and $3 \mathrm{~m}$ height, about SW $45^{\circ}$ inclined slope. The rock in slope profile (a) consists of residual soil and fresh andesite.

b. The slope profile (b) is a $6 \mathrm{~m}$ wide and $4 \mathrm{~m}$ height, about SW $55^{\circ}$ inclined slope. The rock in slope profile $(b)$ consists of residual soil, complete weathered, and fresh andesite. Complete weathered andesite occurred mixing with rounded gravel $(\sim 0.1 \mathrm{~m}$ size) in slope profile (b).

c. The slope profile (c) is a $6 \mathrm{~m}$ wide and 4.5 $\mathrm{m}$ height, about $\mathrm{SW} 60^{\circ}$ inclined slope. The rock in slope profile (c) consists of residual soil, complete weathered, and fresh andesite. Complete weathered andesite occurred mixing with angular gravel $(\sim 0.1 \mathrm{~m}$ size) in slope profile (c).

d. The slope profile $(\mathrm{d})$ is a $6 \mathrm{~m}$ wide and $6 \mathrm{~m}$ height, about SW $65^{\circ}$ inclined slope. The rock in slope profile (d) consists of residual soil, high weathered, and fresh andesite.
High weathered andesites are square rock blocks ( $0.3 \mathrm{~m}$ size) in slope profile (d).

e. The slope profile (e) is a $6 \mathrm{~m}$ wide and $7 \mathrm{~m}$ height, about $\mathrm{SW} 65^{\circ}$ inclined slope. The rock in slope profile (e) consists of residual soil, high weathered, and fresh andesite. High weathered andesites are square rock blocks ( 0.2 $\mathrm{m}$ size) in slope profile (e).

$\mathrm{f}$. The slope profile (f) is a $6 \mathrm{~m}$ wide and $9 \mathrm{~m}$ height, about SW $67^{\circ}$ inclined slope. The rock in slope profile (f) consists of residual soil, complete weathered, and high weathered andesite. Complete weathered andesites occurred mixing with gravel $(\sim 0.1$ $\mathrm{m}$ size) in slope profile (f).

g. The slope profile $(\mathrm{g})$ is a $6 \mathrm{~m}$ wide and 12 $\mathrm{m}$ height, about $\mathrm{SW} 60^{\circ}$ inclined slope. The rock in slope profile $(\mathrm{g})$ consists of residual soil, high weathered, and moderate weathered andesite. High weathered andesites are ( $\sim 0.2 \mathrm{~m}$ size) square rock blocks and moderate weathered andesites are $\sim 0.3 \mathrm{~m}$ size rock blocks in slope profile (g).

h. The slope profile (h) is a $6 \mathrm{~m}$ wide and 18 $\mathrm{m}$ height, about $\mathrm{SW} 55^{\circ}$ inclined slope. The rock in slope profile (h) consists of residual soil, complete weathered, high weathered, and fresh andesite. High weathered andesites are ( $\sim 0.5 \mathrm{~m}$ size) rock blocks. Soil waste disposal covered on fresh andesite of slope profile $(\mathrm{h})$.

i. The slope profile (i) is a $6 \mathrm{~m}$ wide and 22 $\mathrm{m}$ height, about $\mathrm{SW} 55^{\circ}$ inclined slope. The rock in slope profile (i) consists of residual soil, complete weathered, high weathered, and fresh andesite. Complete weathered andesites covered with slicken-sided surfaces. High weathered andesites are $0.3 \mathrm{~m}$ size block. Soil waste disposal covered on fresh andesite of slope profile (i).

$\mathrm{j}$. The slope profile ( $\mathrm{j}$ ) is a $3 \mathrm{~m}$ wide and 27.1 $\mathrm{m}$ height, about $\mathrm{SW} 55^{\circ}$ inclined slope. The rock in slope profile (j) consists of residual soil, complete weathered, high weathered, and fresh andesite. Complete weathered and high weathered andesites covered with slicken-sided surfaces. Soil waste disposal covered on fresh andesite of slope profile (j).

$\mathrm{k}$. The slope profile $(\mathrm{k})$ is a $3 \mathrm{~m}$ wide and 27.1 
TABLE 2. Classification of rock weathering degree based on visual characteristics (ISRM, 2007 in Martin and Stacey, 2018).

\begin{tabular}{lll}
\hline \multicolumn{1}{c}{ Term } & Symbol & \multicolumn{1}{c}{ Description } \\
\hline Fresh & FR/W1 & No visible sign of weathering \\
\hline Slightly weathered & SW/W2 & $\begin{array}{l}\text { Partial }(<5 \%) \text { staining or discoloration of rock substance, usually by } \\
\text { limonite. Color and texture of fresh rock is recognizable. No discernible } \\
\text { effect on the strength properties of the parent rock type. }\end{array}$ \\
\hline Moderately weathered & MW/W3 & $\begin{array}{l}\text { Staining or discoloration extends throughout all of rock substance and other } \\
\text { signs of chemical or physical decomposition are evident. Color and strength } \\
\text { of the original fresh rock is no longer recognizable. }\end{array}$ \\
\hline Highly weathered & HW/W4 & $\begin{array}{l}\text { Limonite staining or bleaching affects all of rock substance. Original color } \\
\text { of fresh rock is no longer recognizable. }\end{array}$ \\
\hline Completely weathered & CW/W5 & $\begin{array}{l}\text { Rock has soil properties (i.e. it can be remoulded and classified according to } \\
\text { the USCS, although texture of the original rock can still be recognizable. }\end{array}$ \\
\hline
\end{tabular}

TABLE 3. Classification of rock chemical weathering degree (Nesbitt and Young, 1982).

\begin{tabular}{cl}
\hline CIA $(\%)$ & \multicolumn{1}{c}{ Weathering degree } \\
\hline $50-60$ & Fresh rock \\
\hline $61-74$ & Slight weathered rock \\
\hline $75-80$ & Moderate weathered rock \\
\hline $81-85$ & $\begin{array}{l}\text { High and Complete } \\
\text { weathered rock }\end{array}$ \\
\hline$>85$ & Residual soil \\
\hline
\end{tabular}

$\mathrm{m}$ height, about $\mathrm{SE} 75^{\circ}$ inclined slope. The rock in slope profile $(\mathrm{k})$ consists of residual soil, slight weathered, and fresh andesite. The surface of slight weathered andesites stained a little in slope profile (k).

1. The slope profile (l) is a $3 \mathrm{~m}$ wide and 20 $\mathrm{m}$ height, about $\mathrm{SE} 75^{\circ}$ inclined slope. The rock in slope profile (1) consists of residual soil, moderate weathered, and fresh andesite. Moderately weathered andesites occur ( $0.2 \mathrm{~m}$ size) rock blocks. Soil waste disposal covered on fresh andesite of slope profile (l).

$\mathrm{m}$. The slope profile $(\mathrm{m})$ is a $5 \mathrm{~m}$ wide and $10 \mathrm{~m}$ height, about SE $75^{\circ}$ inclined slope. The rock in slope profile $(\mathrm{m})$ consists of residual soil, moderate weathered, and fresh andesite. Moderately weathered andesites occur ( $0.1 \mathrm{~m}$ size) rock blocks. Soil waste disposal covered on fresh andesite of slope profile (m).

$\mathrm{n}$. The slope profile $(\mathrm{n})$ is a $5 \mathrm{~m}$ wide and 8 $\mathrm{m}$ height, about $\mathrm{SE} 55^{\circ}$ inclined slope. The rock in slope profile (n) consists of residual soil, and fresh andesite. Soil waste disposal covered on fresh andesite of slope profile (n).

o. The slope profiles (o) and (p) are $5 \mathrm{~m}$ wide and $8 \mathrm{~m}$ height slopes. The rock in slope profiles (o) and (p) consist of residual soil and fresh andesite. Fresh andesite has been disturbed by the exploration process.

p. The slope profile (q) is a $5 \mathrm{~m}$ wide and $8 \mathrm{~m}$ height, about $\mathrm{S} 60^{\circ}$ inclined slope. The rock in slope profiles (q) consists of residual soil, high weathered, and fresh andesite. High weathered andesites are $0.3 \mathrm{~m}$ size rock blocks. Fresh andesites are exploring with backhole in slope profile (q).

q. The slope profile (r) is a $5 \mathrm{~m}$ wide and 8 $\mathrm{m}$ height, about $\mathrm{S} 60^{\circ}$ inclined slope. The rock in slope profiles (r) consists of residual soil, high weathered, and fresh andesite. High weathered andesites are $0.2 \mathrm{~m}$ size rock blocks. Fresh andesites are exploring with backhoe in slope profile (r).

\section{RESUlts}

\subsection{Mineralogical characteristics}

The photographs of typical outcrops and thin sections of the igneous rocks in the Sangon 2 slope have shown in Figure 5 to Figure 8. The corresponding XRD analysis results of the andesite rocks and residual soils have demonstrated in Figure 9 to Figure 18. The fresh rock samples typically consist of $65.83 \%$ plagioclase, $3.70 \%$ quartz, and $7.50 \%$ hornblende (Table 4). Adopting IUGS classification proposed by Streckeisen (1980), the rock in Sangon 2 slope was classified as andesite based 
on the mineral compositions. The rock samples have the porphyro-aphanitic texture with phenocrysts of plagioclase and hornblende and, therefore, could also be called hornblende intrusive andesite porphyry.

The presence of chlorite and calcite as secondary minerals in the andesite rock samples indicated that the parent andesite rock had undergone propylitic hydrothermal alteration. The presence of halloysite, montmorillonite, and mixed smectite/chlorite as secondary minerals in the residual soil samples indicated that the parent andesite rock had undergone additional rock weathering. The percentages of primary minerals (91.90 to $21.40 \%$ ) to secondary minerals $(8.10$ to $78.60 \%)$ of the rock samples based on the results of thin section analyses indicated that the andesite rock samples have undergone weak to high alteration intensities (Table 4).

\subsection{Geochemical characteristics}

Based on the visual characteristics, the Sangon 2 Mine Slope consisted of fresh or unweathered, slight, moderate, high, and complete weathered andesite rocks, and residual soil (Figure 3 and Figure 4). Four major oxides of the rock and soil samples from the XRF analyses can calculate the CIA values. Table 5 described the CIA values of the rock and soil samples. The mine slope consisted of fresh, moderate, high, and complete weathered andesite rocks and residual soil, adopting the chemical weathering classification proposed by Nesbitt and Young (1982). The concentration of $\mathrm{Al}_{2} \mathrm{O}_{3}$ and $\mathrm{SiO}_{2}$ appeared to increase with the increasing of rock weathering. The increase in $\mathrm{SiO}_{2}$ with rocks weathering in the research area appeared to be consistent with that happened in the tropical climate, described by Nesbitt and Young (1982). Other major oxides, particularly $\mathrm{Na}_{2} \mathrm{O}$ and $\mathrm{CaO}$, tended to decrease with the increasing of rock weathering due to leaching. The CIA values increase with the increase in rock weathering degree shown in Table 5 . Rock weathering degrees identified by the visual characteristics appear to be in good agreement with those classified based on the CIA \%.

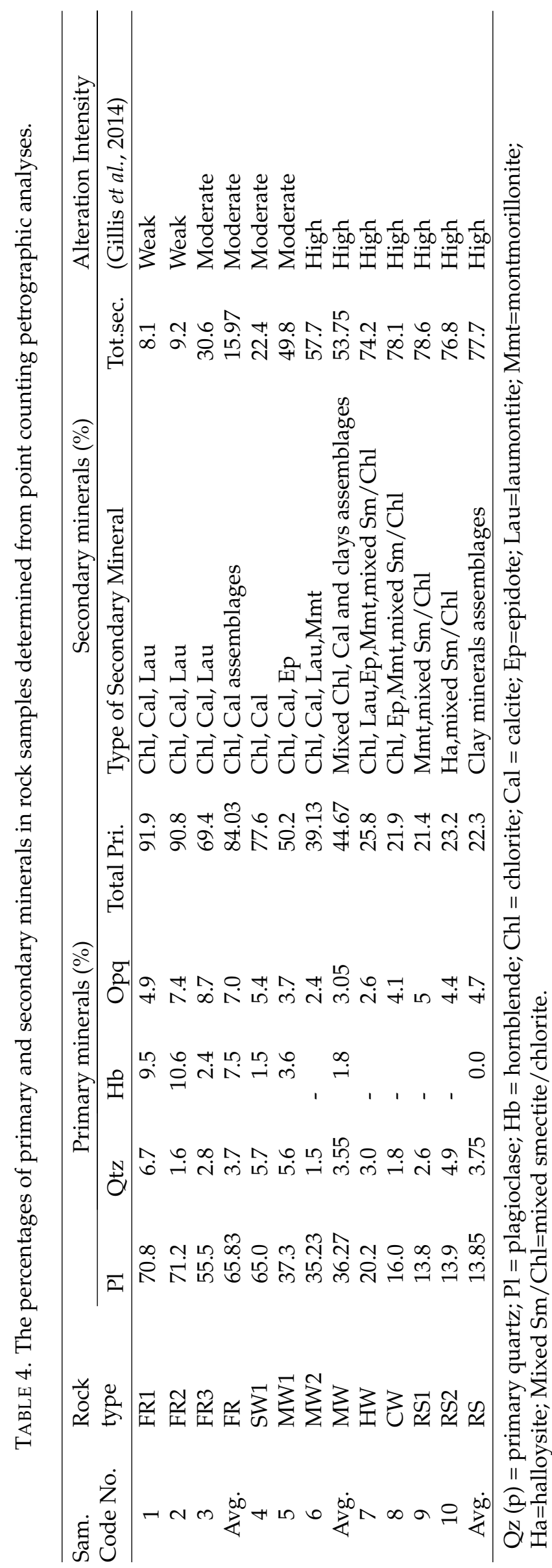




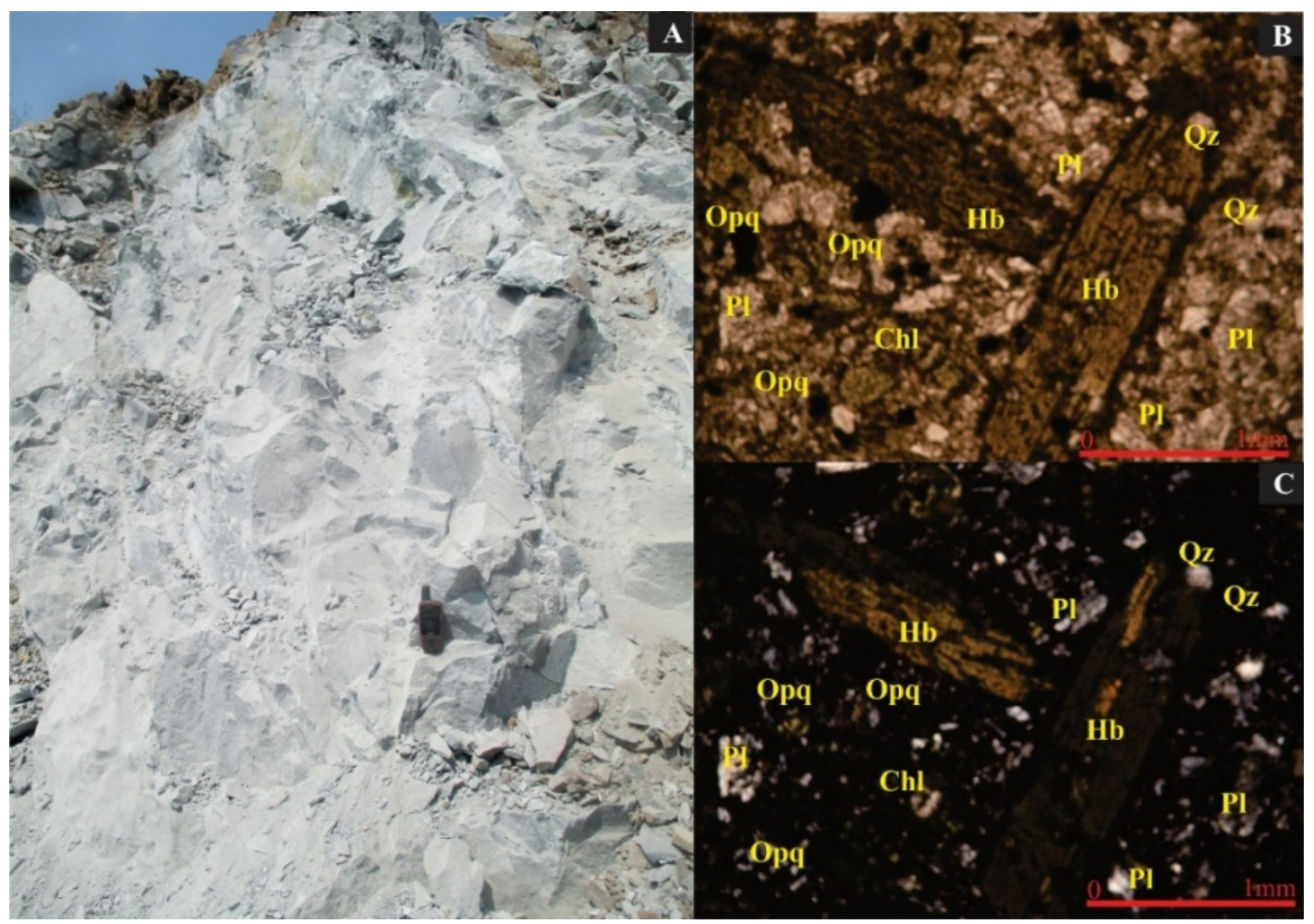

FIGURE 5. Photographs of fresh andesite: (A) Outcrop ; (B) Thin sections FR2 sample under PPL and (C) XPL.

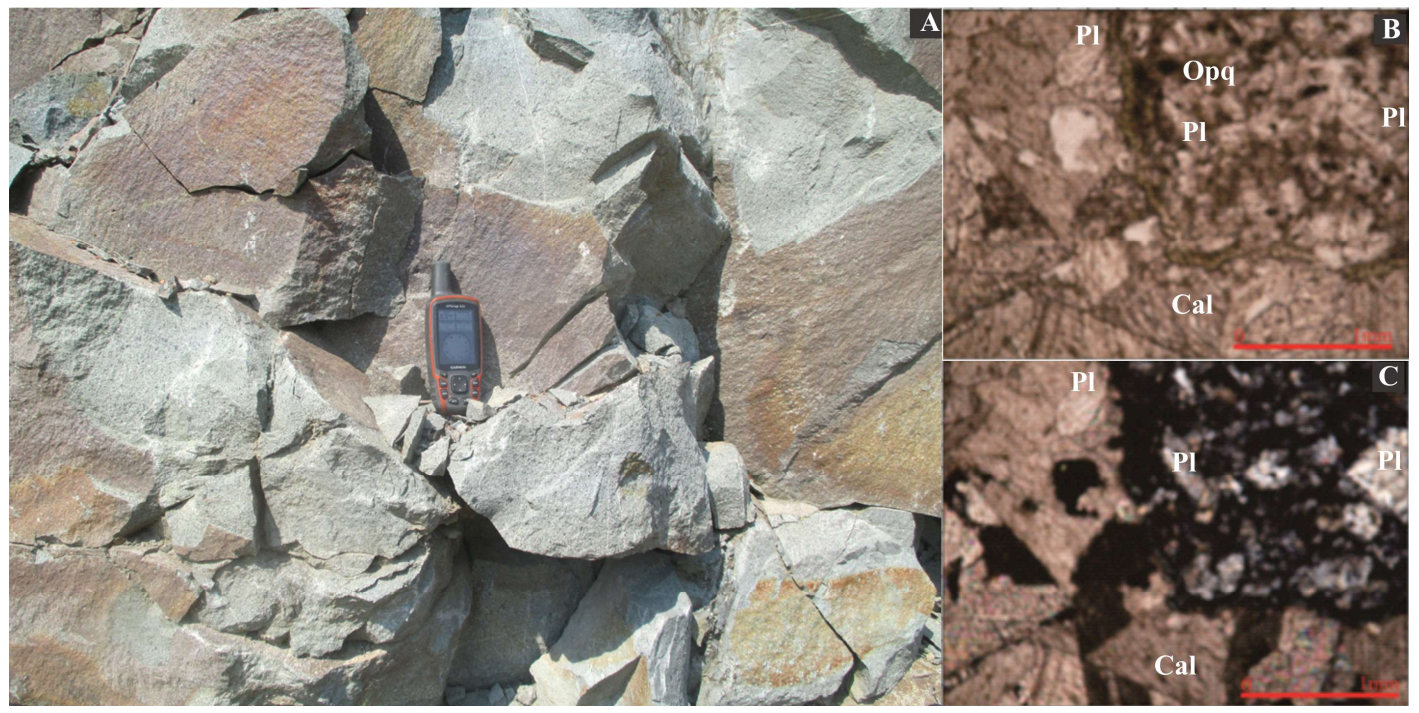

FIGURE 6. Photographs of slightly weathered andesite: (A) Outcrop; (B) Thin sections of SW1 sample under PPL and (C) XPL. 


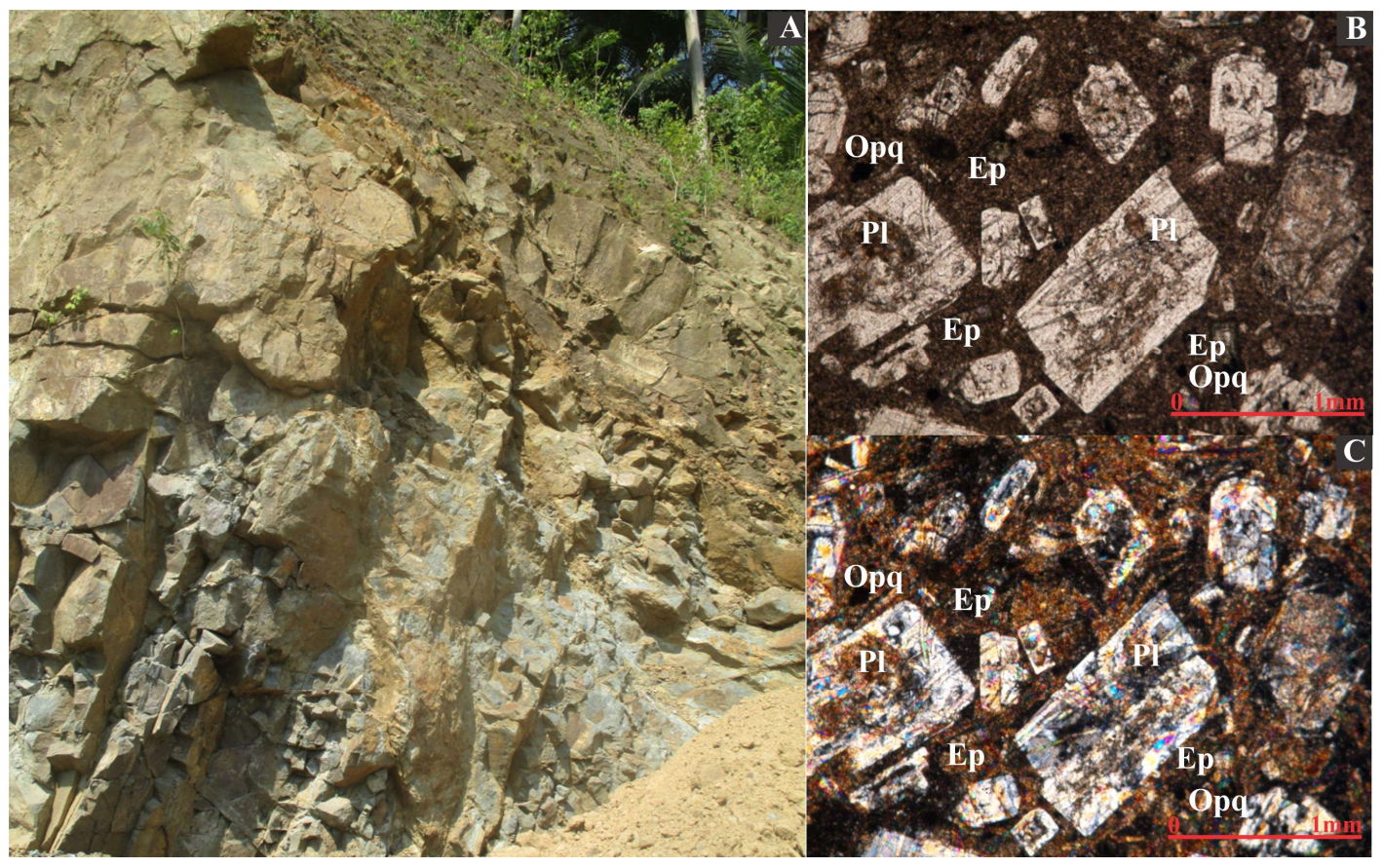

FIGURE 7. Photographs of moderately weathered andesite: (A) Outcrop; (B) Thin sections of MW1 sample under PPL and (C) XPL.

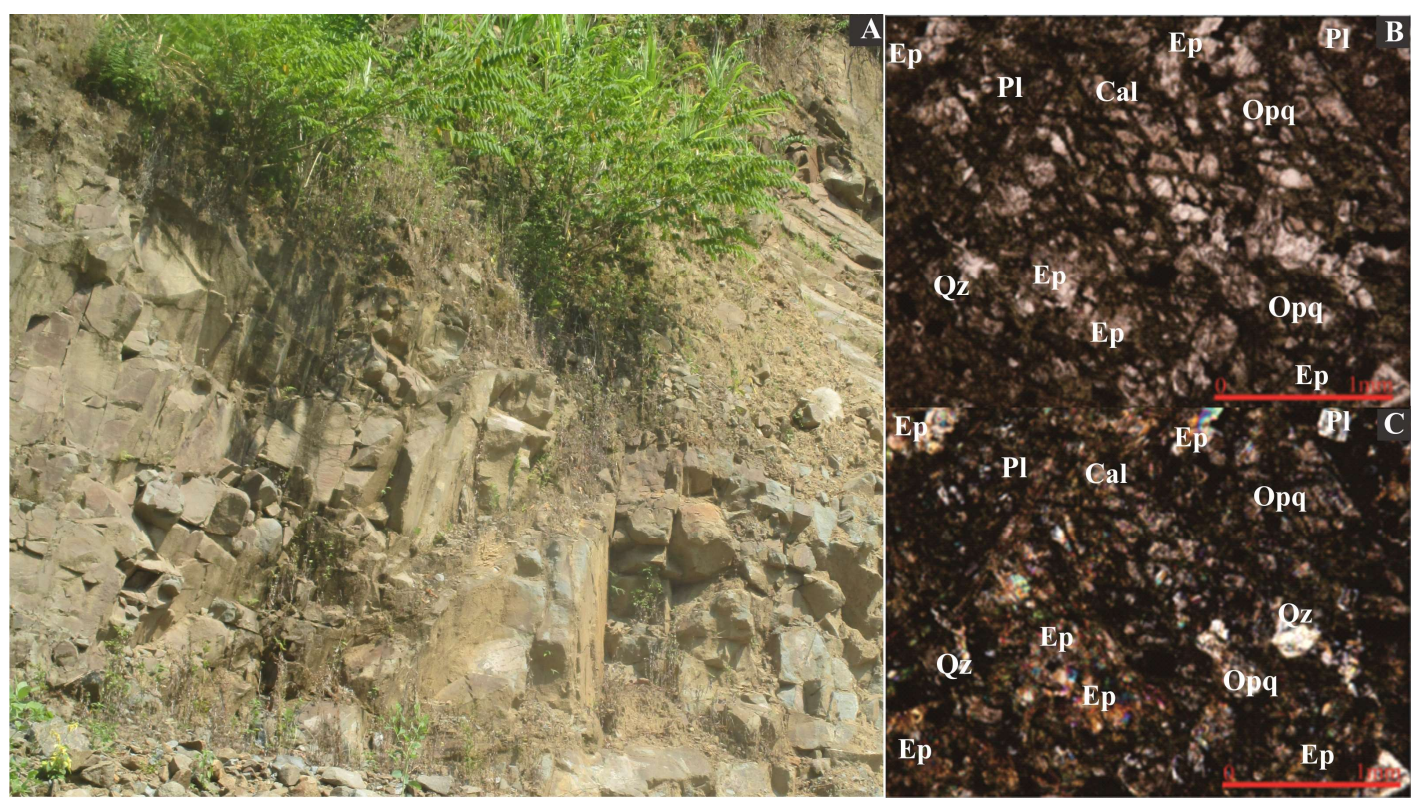

FIGURE 8. Photographs of highly weathered andesite (A) Outcrop; (B) Thin sections of HW sample under PPL and (C) XPL. 


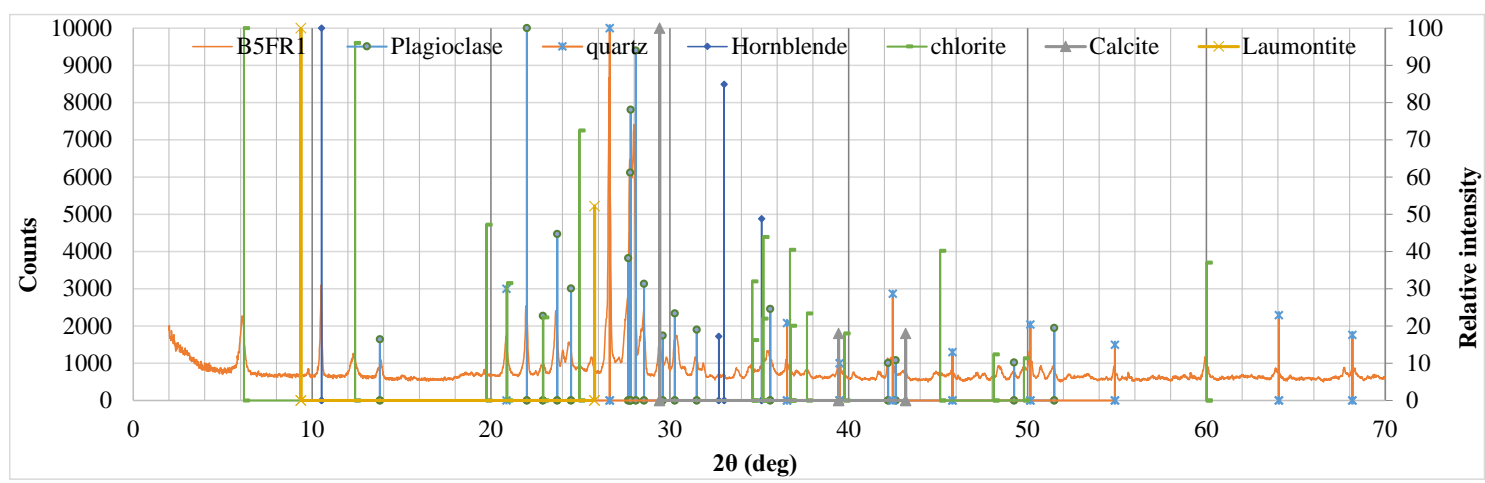

FIGURE 9. XRD analysis results of the fresh andesite (Sample FR1).

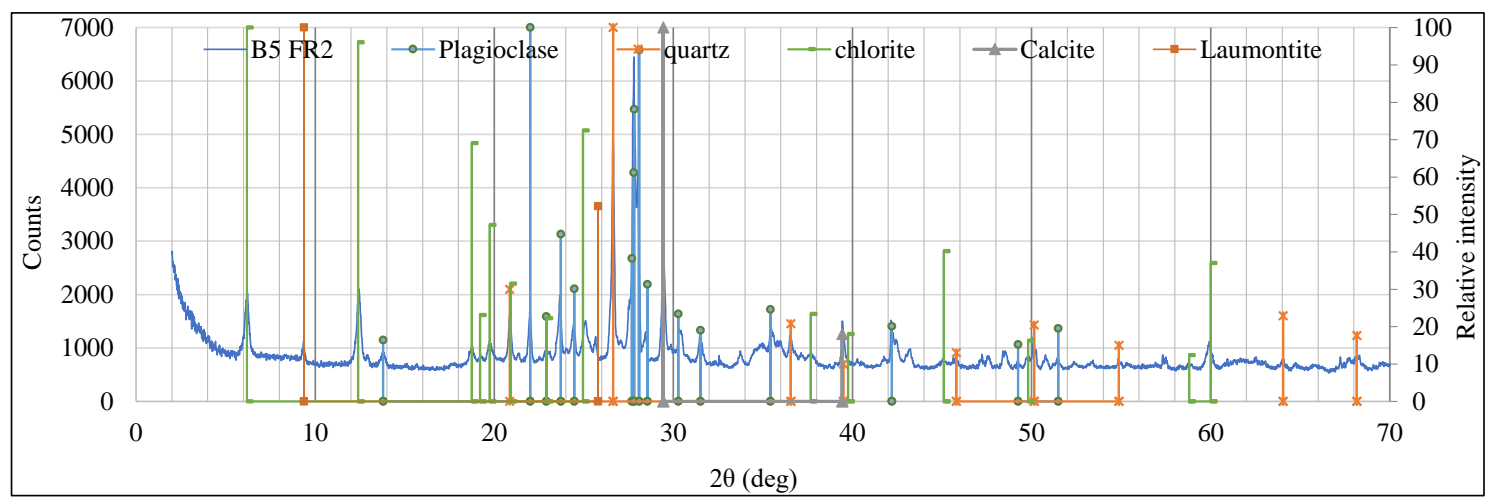

FIGURE 10. XRD analysis results of the fresh andesite (Sample FR2).

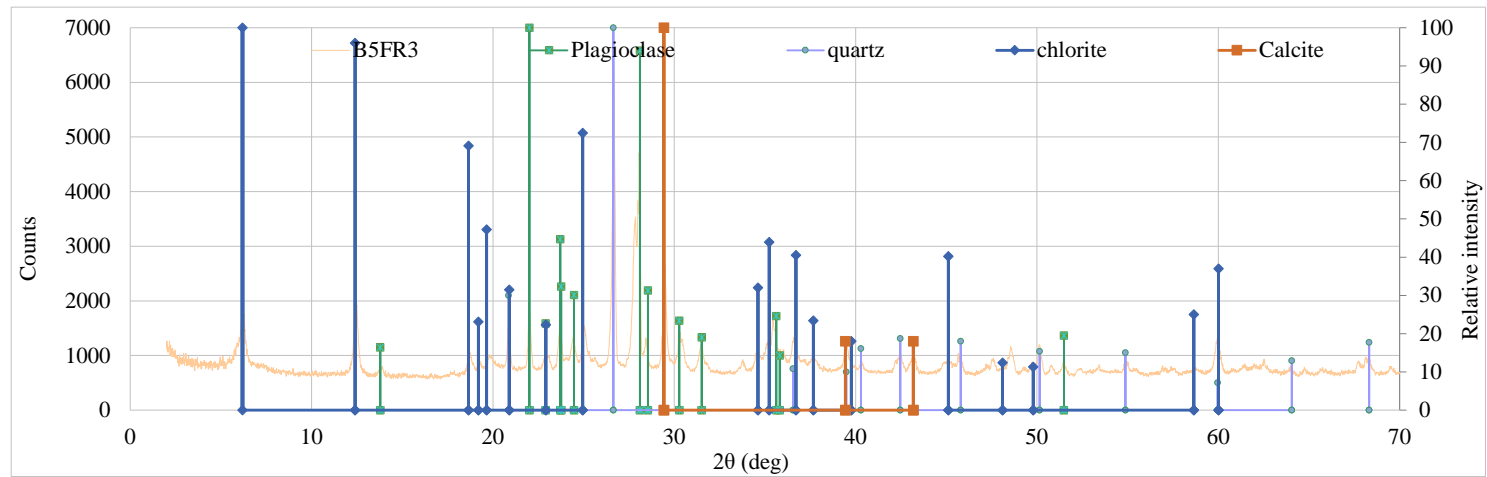

FIGURE 11. XRD analysis results of the fresh andesite (Sample FR3).

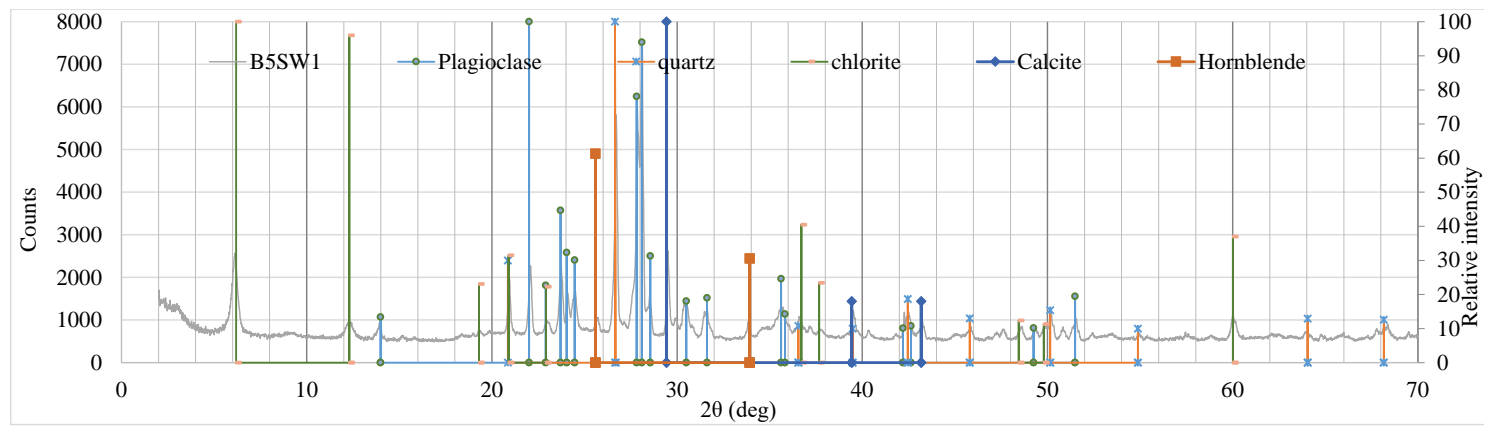

FIGURE 12. XRD analysis results of slightly weathered andesite (Sample SW). 


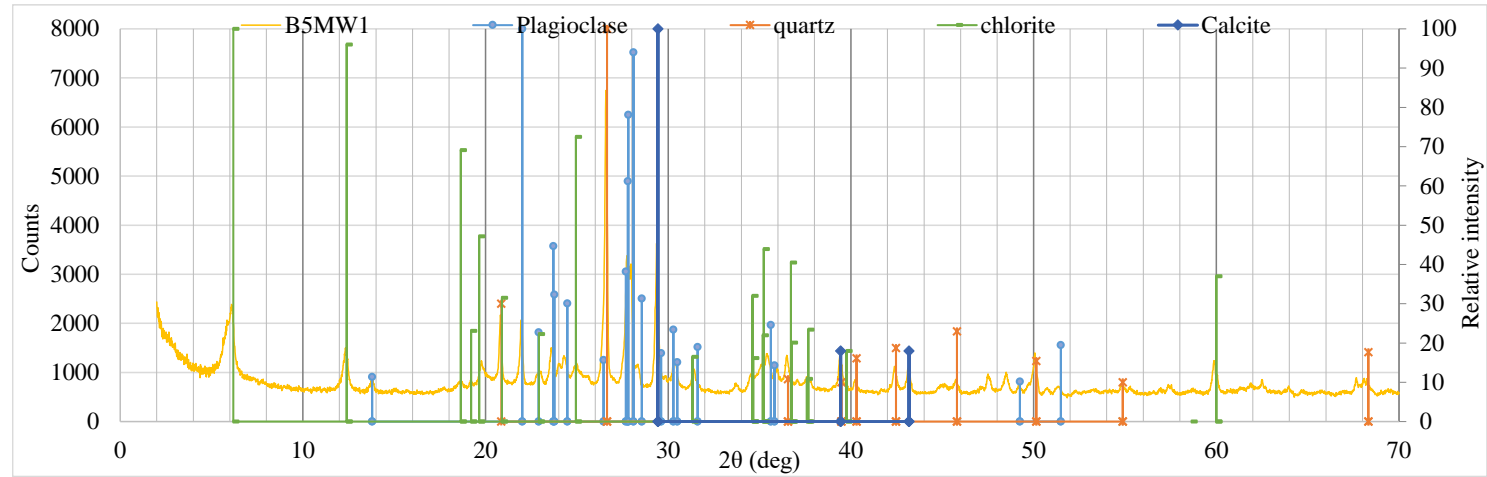

FIGURE 13. The XRD analysis results of moderately weathered andesite (Sample MW1).

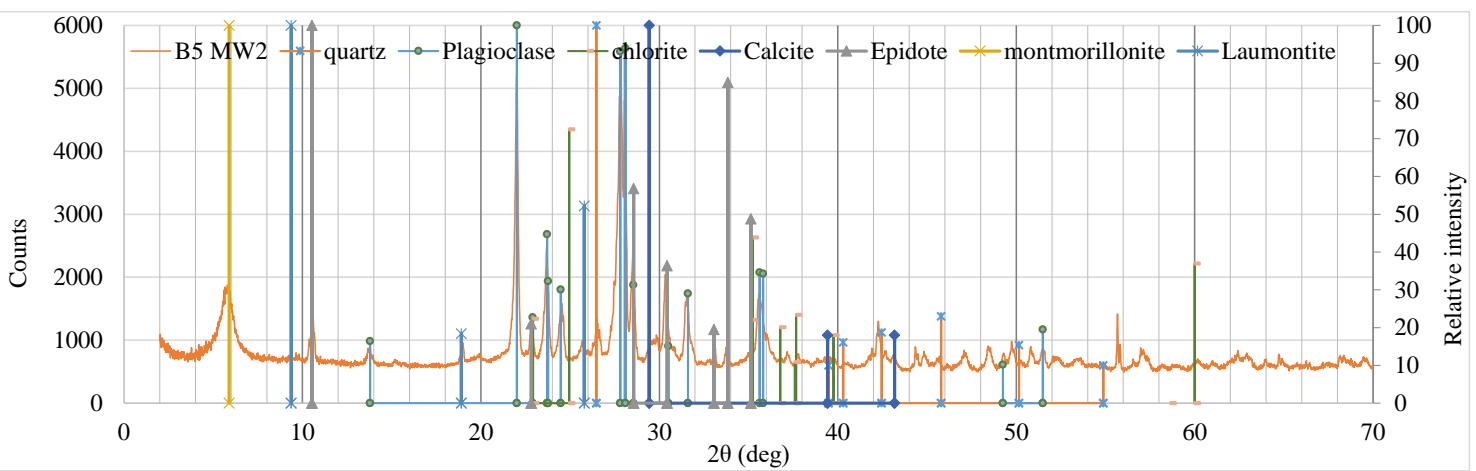

FIGURE 14. The XRD analysis results of moderately weathered andesite (Sample MW2).

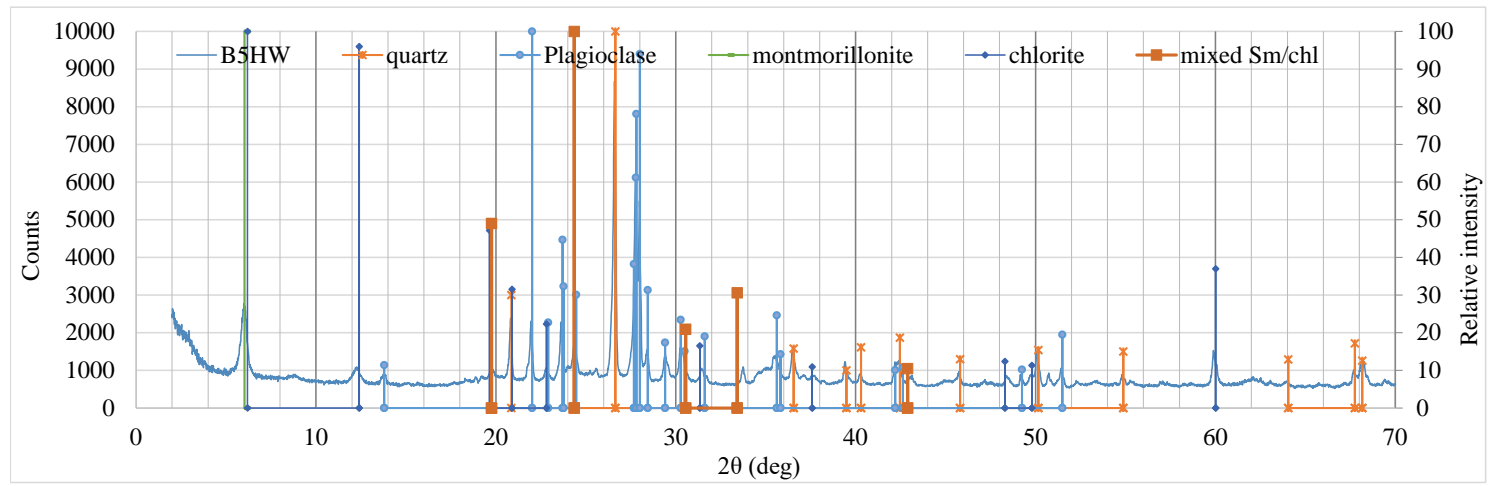

FIGURE 15. The XRD analysis results of highly weathered andesite (Sample HW).

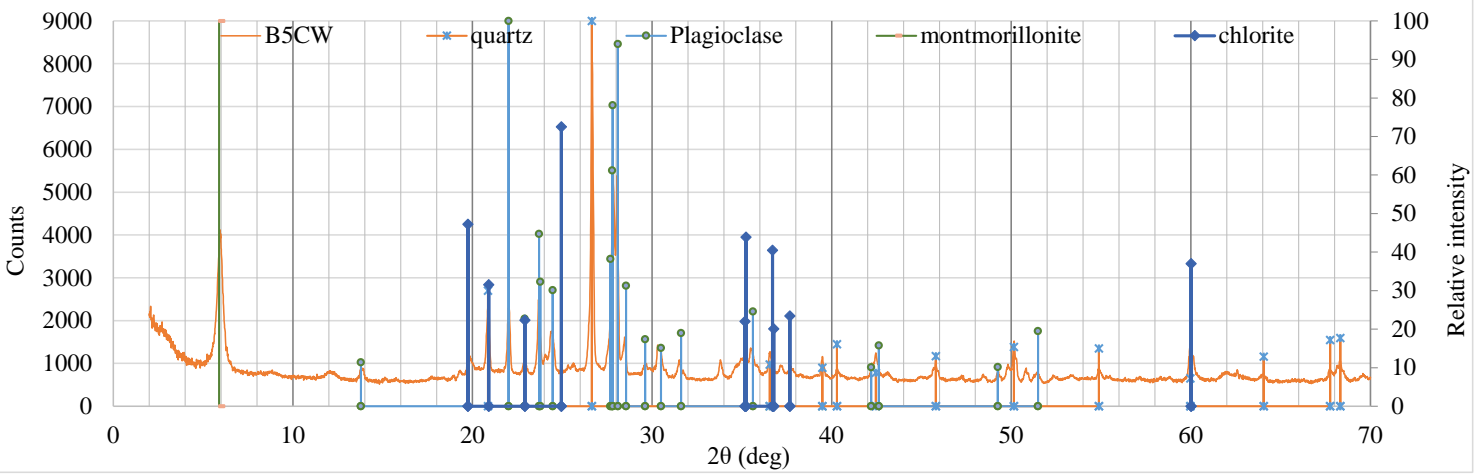

FIGURE 16. The XRD analysis results of completely weathered andesite (Sample CW). 


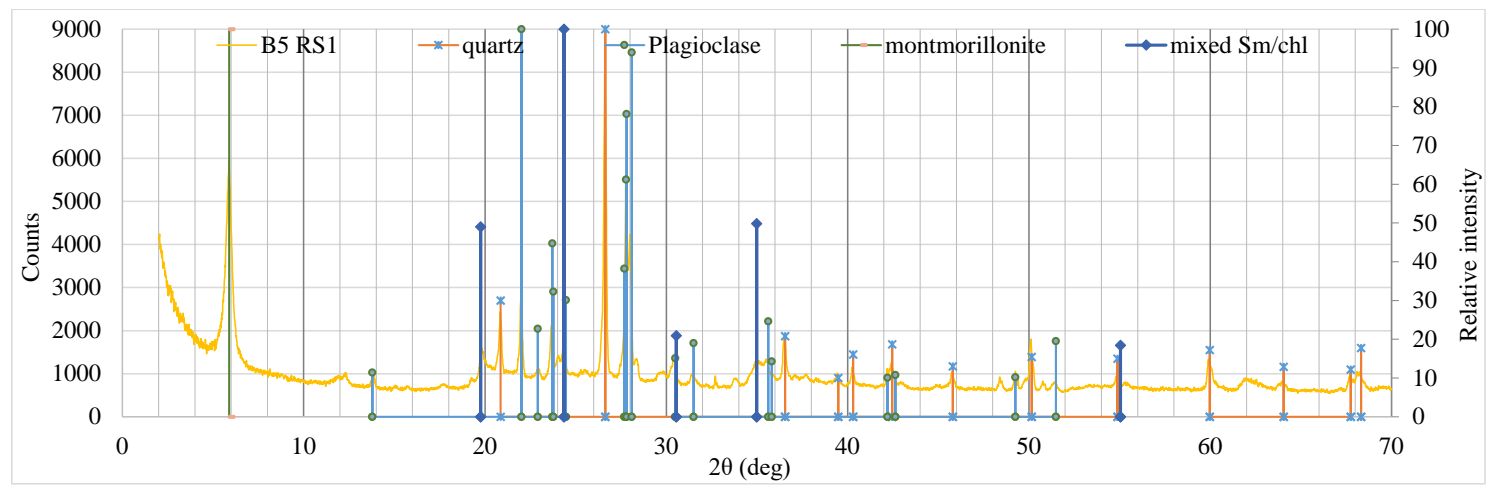

FIGURE 17. The XRD analysis results of residual soil (Sample RS1).

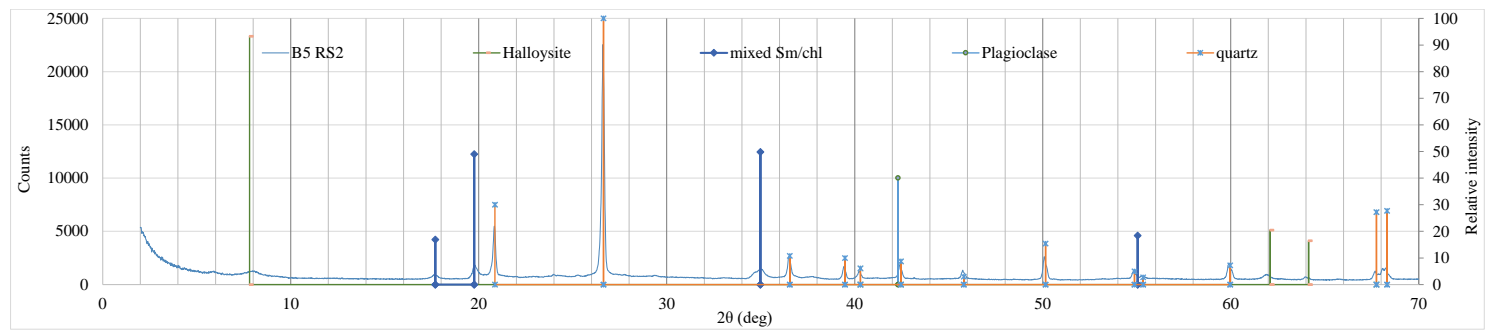

FIGURE 18. The XRD analysis results of residual soil (Sample RS2).

\subsection{Mechanical properties of altered rock}

Rock weathering increased with the decreasing of the UCS values of the rock samples (Table 6). The fresh and moderate weathered andesite rock in Sangon 2 slope had relatively 145.09 to $222.02 \mathrm{MPa}$ (high strength), therefore, classified as very strong rock. Meanwhile, high, complete weathered andesite and residual soil had significantly low compressive strength. Referring to Figure 3, only lower parts of the slope profile likely provided good quality of rocks for use as foundation materials.

The andesite rock in the mine slope consists of several joints has been shown in Figure 4 . The susceptible slope failures occurred in high and complete weathered andesite rock due to the affects of hydrothermal alteration and weathering processes. But the fresh and slight weathered andesite occurred stable slope condition due to little or no affects of these processes. The strong rocks are likely controlled by the joint characteristics (e.g., orientation, spacing, aperture) described by Hoek and Brown (1997), and Hoek (2007). Further study to investigate the characteristics of joints developed andesite rocks and the associated slope stability still required for mine slope design.

\section{Discussion AND CONCLUSIONS}

Based on the visual characteristics, Sangon 2 slope consists of fresh, slight, moderate, high, complete weathered andesite rock, and residual soil. Weak zone (WZ) and strong andesite rocks zone (SARZ) occurred in Sangon 2 slope based on the rock characteristics. High, complete weathered andesite rock and residual soil found in weak zone where is the upper part of the slope profiles. Meanwhile, fresh rock andesite, slight and moderate weathered andesite rock found in strong andesite rock zone (SARZ) where is the lower part of the mine slope profiles.

The research investigated the mineralogical, geochemical, and mechanical properties of the rock in Sangon 2 Mine Slope due to the influence of hydrothermal alteration and weathering. The results showed that the fresh rock typically consisted of $65.83 \%$ plagioclase, $3.70 \%$ quartz, and $7.50 \%$ hornblende, classified as andesite. The presence of secondary minerals assemblage (chlorite and calcite) of fresh andesite rock samples indicated that the parent andesite rocks had undergone propylitic hydrothermal alteration at depth covering with the weathered rocks. The presence of secondary minerals assemblage (halloysite, montmorillonite, 


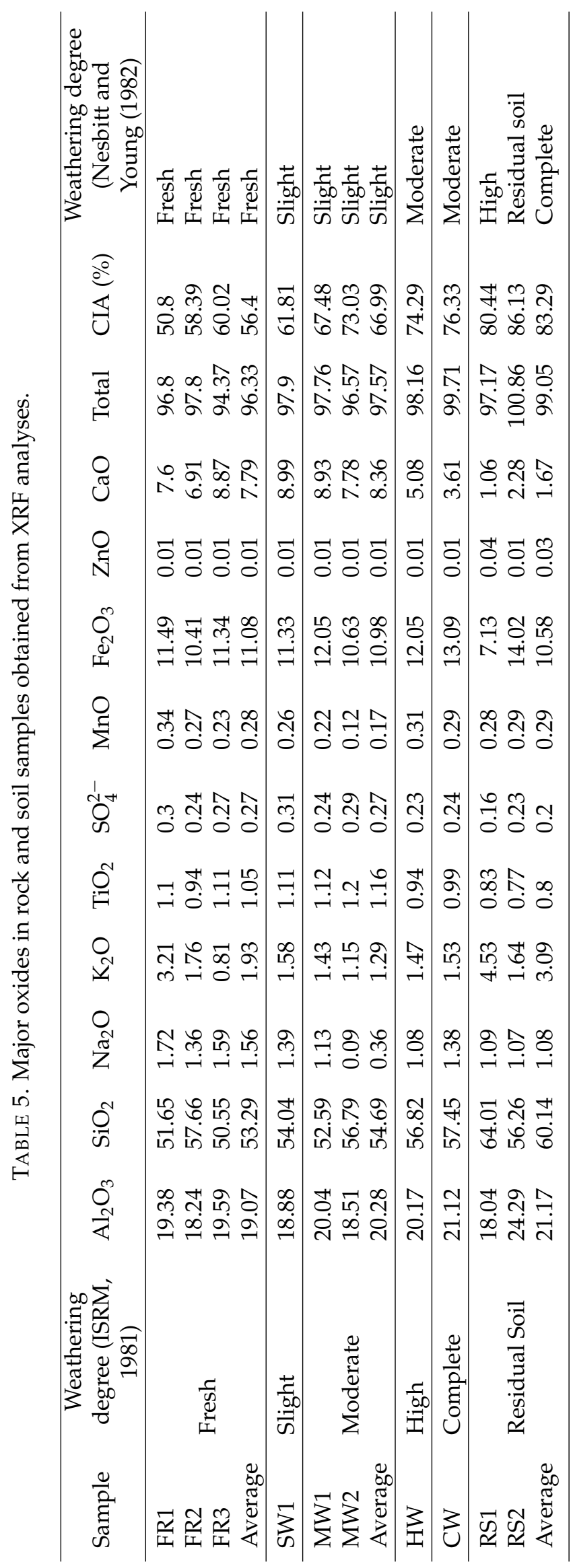

TABLE 6. UCS values of rock samples.

\begin{tabular}{|c|c|c|c|c|}
\hline Sample & $\begin{array}{l}\text { Weathering } \\
\text { degree } \\
\text { (ISRM, } \\
\text { 1981) }\end{array}$ & $\begin{array}{l}\text { Is(50) } \\
(\mathrm{MPa})\end{array}$ & $\begin{array}{l}\text { UCS } \\
(\mathrm{MPa})\end{array}$ & $\begin{array}{l}\text { Rock clas- } \\
\text { sification } \\
\text { (ISRM, } \\
\text { 1981) }\end{array}$ \\
\hline $\begin{array}{l}\text { FR1 } \\
\text { FR3 }\end{array}$ & Fresh & $\begin{array}{l}9.25 \\
7.92 \\
\end{array}$ & $\begin{array}{l}222.02 \\
190.19\end{array}$ & $\begin{array}{l}\text { Very } \\
\text { strong }\end{array}$ \\
\hline MW & Moderate & 6.05 & 145.09 & $\begin{array}{l}\text { Very } \\
\text { strong }\end{array}$ \\
\hline HW & High & 0.2 & 4.78 & Very weak \\
\hline $\mathrm{CW}$ & Complete & 0.02 & 0.41 & Hard clay \\
\hline
\end{tabular}

mixed smectite/chlorite) of the residual soil samples indicated that the parent andesite rock had undergone high alteration intensity and rock weathering intensively.

The key minerals assemblage, halloysite, mixed smectite/chlorite based on XRD analysis results with high intensity alteration (percentage of primary minerals, $23.20 \%$ and CIA 86.13 $\%)$, is widely distributed in Sangon 2 mine. Clay minerals assemblage of residual soil that is the most problematic clays as slope forming materials for mine slope stability. The compressive strength values of the rock samples from strong andesite rocks zone to weak zone decrease from 222.02 $\mathrm{MPa}$ (very strong) to 0.41 $\mathrm{MPa}$ (very weak). Good quality rock andesite for foundation materials were distributed 68.56 $\%$ regionally in Kokap District, described by Lenggono et al. (2018). For two-years exploration period, the volume distribution of strong rock andesite zone in Sangon 2 mine changed and remained as the distribution of weak zone $(\sim 70 \%)$ by high chemical weathered andesite rock based on the results of mineralogical characterization, geochemical composition (CIA) and compressive strength in addition to visual observation analyses. The weak zone consists of clay mineral assemblage residual soil can occur more susceptible slope failures by the decreasing of mineralogical, geochemical and engineering properties (Phyu, 2020).

\section{ACKNOWLEDGEMENTS}

The authors would like to thank to JICA (Japan International Cooperation Agency) and AUN/SEED-Network (ASEAN University Network/Southeast Asia Engineering Development Network) for financial support to carry out this research. The first author would like 
PHYU et al.

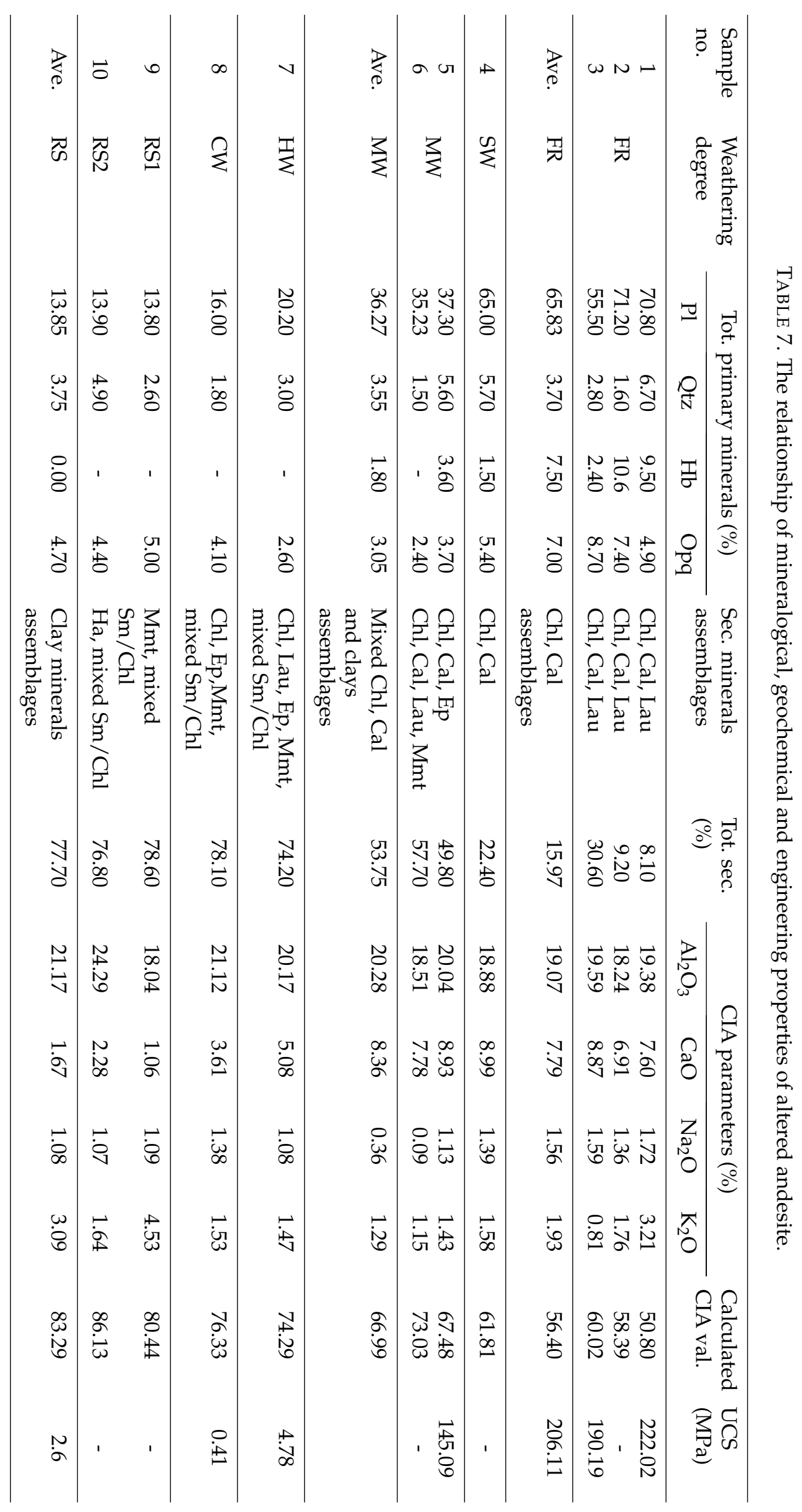


to express my gratitude to Dr. Noriyuki Arai from Uji Campus, Kyoto University for assisting the XRD and XRF analyses. The assistance of Mr. Diyan Aditya Putra Pratama, Ms. Nar Rahmi Amalia, Ms. Dwi Putri Alcrista Gultom, Ms. Diyaning Ratri, and Mr. Faqih Zakky A in conducting field observation and laboratory testing are appreciated gratefully.

\section{REFERENCES}

Byers F. M. (1990) Procedure for determination of volume constituents in thin section of rocks, Los Alamos National Laboratory, Yucca Mountain Project, p. 8.

Franklin, J. A. (1985) April. Suggested method for determining point load strength. In International Journal of Rock Mechanics and Mining Sciences \& Geomechanics Abstracts (Vol. 22, No. 2, pp. 5160). Pergamon. https://doi.org/10.1016/01489062(85)92327-7.

Gillis, K.M., Snow, J. E., Klaus, A., Guerin, G., Abe, N., Akizawa, N., Ceuleneer, G., Cheadle, M. J., Adriao, A., Faak, K. and Falloon, T. J. (2014) Expedition 345 summary. In Proceedings of the Integrated Ocean Drilling Program (Vol. 345, pp. 149). https://doi:10.2204/iodp.proc.345.101.2014.

Hoek, E. and Brown, E. T. (1997) Practical estimates of rock mass strength. International journal of rock mechanics and mining sciences, 34(8), pp.1165-1186. https://doi.org/10.1016/S13651609(97)80069-X.

Hoek, E. (2007) Rock Mass Properties. Practical rock engineering, pp.190-236. Lenggono, T., Putra D.P.E. and Setianto A. (2018) The Quality and Distribution of Andesite Rock for
Construction Materials in Kokap and Temon District, Kulon Progo Regency, YogyakartaIndonesia. Journal of Applied Geology, 3(2), pp.22-31. https://doi.org/10.22146/jag.48595.

Makealoun, S., Putra, D.P.E. and Wilopo, W. (2014) Landslide Susceptibility Assessment of Kokap Area Using Multiple Logistic Regression. Journal of Applied Geology, 6(2). Nesbitt, H.W. and Young. G.M. (1982) Early Proterozoic climates and plate motions inferred from major element chemistry of lutites. Nature, 299(5885), pp. 715717.

Phyu, H. T. (2020) Characteristics of altered andesite rock. Stability of altered intrusive rock slopes in Kulon Progo Mountains, Yogyakarta Special Region, Indonesia (Unpublished doctoral dissertation). Chapter 5, Geological Engineering Department, Faculty of Engineering, Universitas Gadjah Mada, Yogyakarta Special Region, Indonesia, pp. 61-85.

Pratama, D. A. P., Indrawan I G. B. and Warmada I W. (2018) Mineralogical characteristics of hydrothermally altered andesite in Kalirejo Village and the Surrounding Areas, Indonesia. Journal of Applied Geology, 3(2), pp.48-57. https://doi.org/10.22146/jag.48598.

Rahardjo, W., Sukandarrumidi and Rosidi, H. M. D. (1995) Geological Sheet Map of Yogyakarta, 1 : 100.000, Directory of Geology, Bandung, Indonesia.

Streckeisen, A. (1980) Classification and nomenclature of volcanic rocks, lamprophyres, carbonatites and melilitic rocks IUGS Subcommission on the Systematic of Igneous Rocks. Geol Rundsch 69, 194-207. https://doi.org/10.1007/BF01869032. 